\title{
Long-Run Gains From International Equity Diversification: Taiwan's Evidence, 1995-2001
}

\author{
Chien-Chung Neih \\ Tamkang University \\ Tsangyao Chang \\ Feng Chia University
}

\begin{abstract}
This study attempts to explore whether there exist long-run gains from international equity diversification for Taiwan investors who invest in the stock markets of its major trading partners, namely those of Hong Kong, Japan, Singapore, South Korea, and the United States. We further incorporate two dummies, taking into account two financial shocks of the stock crash of the United States in 1997 (D97) and the Asian financial crisis (DAC), into our model. The results indicate that these six stock markets are cointegrated with one cointegrating vector, which implies that the efficient market hypothesis (EMH) is violated in this multinational stock markets and the Taiwan investors may not benefit from portfolio diversification in the stock markets of its major trading partners. However, the dropping of either Singapore or South Korea markets from the portfolios leads to a rejection of cointegration and hence implies gains from diversification. Our results argue that analysis of more extensive investment portfolios and the drawing of conclusions regarding portfolio diversification must be carried out with great care for Taiwan investors.
\end{abstract}

- JEL Classifications: C32, F21

\footnotetext{
*Corresponding address: Professor Chien-Chung Nieh, Tamkang University, Department and Graduate Institute of Banking and Finance, Tamsui, 251, Taipei Hsien, Taiwan, ROC. Tel: $+886-2-26215656$ ext.2591, Fax: +886-2-26214755, E-mail: niehcc@mail.tku.edu.tw Professor Tsangyao Chang FengChia University, Department and Graduate Institute of Economics, Taichung, Taiwan. Tel: +886-424517250 ext.4484, E-mail: tychang@fcu.edu.tw.

(C2003-Center for International Economics, Sejong Institution, All Rights Reserved.
} 
- Key words: Long-run gains, Stock market, Equity diversification, Cointegration, Efficient market hypothesis

\section{Introduction}

Over the past two decades a vast amount of research has been devoted to studying the interdependence among national equity markets, especially in the wake of the October 1987 crash which caused correlated stock price movements across international stock markets. ${ }^{1}$ Previous empirical studies have employed cointegration techniques to explore international equity market linkages. The study of MacDonald and Taylor (1989) argues that asset prices from two different efficient markets cannot be cointegrated. Specifically, if a pair of stock prices is cointegrated, one stock price can be forecast (is Granger-caused) by the other. Thus, cointegration is inconsistent with weak form efficiency. These cointegration results suggest that there are no gains from portfolio diversification.

Most studies are centralized in examining the long-run gains for the investors of the large industrialized countries. For example, potential long-run benefits from international diversification between the U.S. and Japan, and the stock markets in French, German and the UK during the pre and post October crash are found in Arshanapalli and Doukas (1993). Which examining the linkages and dynamic interactions among five stock markets using pairwise cointegration and errorcorrection models. Same conclusions of the existence of potential long-run benefits in risk reduction from diversifying in US stocks and stocks in any of the major European markets are found in Kanas (1998). ${ }^{2}$ In contrast to Arshanapalli and Doukas (1993) and Kanas (1998), this result of Hassan and Naka (1996) suggests that the benefits from international diversification among the U.S., Japan, U.K. and Germany stock markets are not obtainable. Hassan and Naka (1996) investigated the dynamic linkages among the U.S., Japan, U.K. and German stock market indices using multivariate cointegration and error-correction models and significantly found that both short-run and long-run relationships among these

${ }^{1}$ Literature investigating the effect of 1987 stock crash on the linkage among international equities can be found in Arshanapalli and Doukas (1993), Arshanapalli, Doukas and Lang (1995) and Masih and Masih (1997b)

${ }^{2}$ Kanas (1998) employed the Phillips and Ouliaris's (1990) multivariate trace statistic, the Johansen methods, and the recently proposed Bierens's (1997) nonparametric approach to test for pairwise cointegration between the US and six largest European equity markets. 
four industrialized countries' stock indices are existed.

Recently, considerable attention has been given to possible linkages and interdependencies in major Asian countries. Chan, Gup and Pan (1992), Chowdhury (1994), Roger (1994) and Kwan, Erisccos and Dolado (1995), using cointegration tests and vector autoregressive analysis, report that international diversification in major countries are effective. Arshanapalli, Doukas and Lang (1995) examine the links and dynamic interactions between the U.S. and six major Asian stock markets before and after October 1987 and find a long-run equilibrium relationship between the U.S. and Asian stock market movements during the post-October 1987 period. This result suggests that the benefits from international diversification between U.S. and the Asian equity markets have substantially reduced since October 1987. Masih and Masih (1997a) also tested for multivariate cointegration between four Asian Newly Industrializing Countries stock markets - Taiwan, South Korea, Singapore, and Hong Kong - in models incorporating the established markets of the U.S., Japan, UK and Germany and reached the same conclusions.

The objective of this study is to explore whether there exist long-run gains from international equity diversification for Taiwan investors who invest in the equity markets of its major trading partners, namely those of Hong Kong, Japan, Singapore, South Korea and the United States over the period January 5, 1995 to February 16, 2001. The main reasons for us to chooses these five countries is that the share of exports and imports from Taiwan to these five countries were relatively high about $61.8 \%$ and $51.8 \%$, respectively, at the end of 1999. In order to fully investigate the long-run relationship among variables during our samples period selected, we incorporate two dummies, taking into account two financial shocks of the stock crash of the United States in 1997 (D97) and the Asian financial crisis (DAC), into our model. We explore the potential for long-run diversification gains for Taiwan investors by examining whether Taiwan market is multivariated cointegrated with the stock markets of the Hong Kong, Japan, Singapore, South Korea and the United States. The results from Johansen (1988) and Johansen and Juselius's (1990) multivariate cointegration test indicate that these six stock markets are cointegrated with one cointegrating vector. This implicates that the efficient market hypothesis (EMH) is violated in this multivariate context and the Taiwan investors may not yield portfolio diversification from these countries in the long run. However, the dropping of either Singapore or South Korea markets from the portfolios leads to a rejection of 
cointegration and hence implies gains from portfolio diversification. Our results suggest that analysis of more extensive investment portfolios and the drawing of conclusions regarding portfolio diversification must be carried out with great care for Taiwan investors over this sample period. These results are valuable to Taiwan individual investors and financial institutions holding internationally diversified long-run investment portfolios.

The major motivations for this study are several folds. First, Taiwan is a rapidly expanding emerging market and a significant number of Taiwan investors have adopted diversification benefits as the primary criterion in investing outside Taiwan. Second, the rapid growth of the Taiwan economy has attracted the attention of international investors and both Dow Jones and Morgan Stanley have put Taiwan stocks into their international indexes since September 1997. This suggests that the issue of international linkages of the Taiwan share market is of practical interest to a significant number of international investors. Third, little evidence is available on the long-run linkages of Taiwan share markets and its implications for long-run benefits from international equity diversification.

The remainder of this study is organized as follows. Section II presents the data used. Section III presents the methodologies used and discusses the empirical results. Finally, Section IV concludes.

\section{Data}

Our empirical analysis employs daily data on stock price indexes for Taiwan and its major trading partners, namely those of Japan, Hong Kong, Singapore, South Korea, and the United States over the period of January 5, 1995 to February 16, 2001. The representative indexes used in the analysis are shown in Table 1. The daily closing price index data are collected from the Taiwan Stock Exchange and the AREMOS of the Ministry of Education, Taiwan. All the indexes are based on local currencies. Following the Chowdhury's (1994) study, the time series data have been adjusted by dropping some entries, including the Saturday entries, to guarantee that each country has an entry on given date. According to Chowdhury (1994), this method may take care of data gap caused by holidays and other nonworking days. Therefore, the total number of observations for each country is 1247. All series are measured in natural logs. Causal observation suggests that each stock price series appears to be nonstationary and that these six national stock price indexes tend to move more or less together over time, a result 
Table 1. The Representative Stock Price Indexes

\begin{tabular}{ll}
\hline Country & \multicolumn{1}{c}{ Stock Index } \\
\hline Taiwan & Weighted Index \\
Hong Kong & Heng Seng Index \\
Japan & Nikkei Stock Average \\
Singapore & Strait Index \\
South Korea & Composite Index \\
USA & Dow Jones Industrial Index \\
\hline
\end{tabular}

which is later confirmed through the use of cointegration technique.

\section{Methodology and Empirical Results}

\section{A. Unit Root Tests of National Stock Price Indices}

Recent studies have found that many macroeconomic and financial time series, including stock price series, contain unit roots dominated by stochastic trends (see Nelson and Plosser, 1982; Lee and Jeon, 1995). A necessary but not sufficient

Table 2. Unit Root Tests for individual stock price indices:

(January 5, 1995 to Feburary 16, 2001)

\begin{tabular}{|c|c|c|}
\hline \multicolumn{2}{|c|}{ Panel A: Augmented Dickey-Fuller } & \multirow[t]{2}{*}{ Panel B: Phillips-Perron } \\
\hline \multicolumn{2}{|c|}{ Levels } & \\
\hline $\mathrm{TN}$ & $-1.516(4)$ & $-1.606[7]$ \\
\hline HK & -1.976 (4) & $-1.836[7]$ \\
\hline JP & $-1.389(4)$ & $-1.487[7]$ \\
\hline SP & $-1.529(4)$ & $-1.579[7]$ \\
\hline SK & $-1.623(4)$ & $-1.612[7]$ \\
\hline US & $-2.016(4)$ & $-1.980[7]$ \\
\hline \multicolumn{3}{|c|}{ First-differences } \\
\hline $\mathrm{TN}$ & $-15.737 *(4)$ & $-33.998 *[7]$ \\
\hline HK & $-15.657 *(4)$ & $-35.413 *[7]$ \\
\hline JP & $-16.164 *(4)$ & $-36.618^{*}[7]$ \\
\hline SP & $-14.781 *(4)$ & $-30.638 *[7]$ \\
\hline SK & $-16.470 *(4)$ & $-33.355 *[7]$ \\
\hline US & $-15.865^{*}(4)$ & $-35.476^{*}[7]$ \\
\hline
\end{tabular}

Note: 1 . The number in the parenthesis indicates the appropriate order of the ADF model.

Lags were chosen based on the Campbell and Perron's (1991), method.

2. The number in the bracket indicate the lag truncation for Bartlett kernel suggested by NeweyWest test (1987).

3. *indicates significance at $5 \%$ level. 
condition for cointegration is that each of the stock price index series should be integrated of the same order (or I(1), see Granger, 1981). In this study, unit root is tested using both Augmented Dickey-Fuller (ADF) (1981) and Phillips-Perron (PP) (1988) tests. Panel A in Table 2 reports the results of non-stationary tests for Taiwan, Hong Kong, Japan, Singapore, South Korea, and the U.S. stock price indexes using augmented Dickey-Fuller tests. According to the applicable test statistics reported by Mackinnon (1991), non-stationarity can not be rejected for the levels of each stock price series at the 5-percent significance level based on ADF test. In contrast, when the data are differenced, non-stationarity can be rejected for all data series. These results imply that each stock price index are integrated of order one (or I(1)). The forms of I(1) series for all the stock indices are further confirmed by the P-P test as shown in Pane B of Table 2.

\section{B. Cointegration Tests}

Given unit roots, the issue arises whether there exists some long-run equilibrium relationship among stock price indexes. The existence of long-run equilibrium relationship among variables is referred to literature as cointegration. According to Granger (1981), a vector of variables, $Y_{t}$ is said to be cointegrated of order $(\mathrm{d}, \mathrm{b})$ - denoted CI $(\mathrm{d}, \mathrm{b})$ - if all the elements of $Y_{t}$ are integrated of the same order $d$ and there exists a linear combination of these elements, which is integrated of order (d-b) (ie., I(d-b) with $b>0$ ). Cointegration tests in this study are conducted using the multivariate maximum likelihood methedology developed by Johansen (1988) and Johansen and Juselius (1990). This procedure is currently the most reliable test for cointegration and avoids the problems with the Engle and Granger's (1987) two-step procedure, as shown in Kremers, Erisccos and Dolado (1992) and in Gonzalo (1994).

Following Johansen (1988) and Johansen and Juselius (1990), we construct a pdimensional vector autoregressive model with Gaussian errors, expressed by its first-differenced error correction from as

$$
\Delta Y_{t}=\Gamma_{1} \Delta Y_{t-1}+\Gamma_{2} \Delta Y_{t-2} \ldots+\Gamma_{k-1} \Delta Y_{t-(k-1)}+\Pi Y_{t-1}+\psi D_{t}+\varepsilon_{t}
$$

where $Y_{t}$ is the vector of the national stock series studied; $\varepsilon_{t}$ is i.i.d. $\mathrm{N}(0, \Sigma)$,a white noise process; $\Gamma_{i}=-I+A_{1}+A_{2}+\ldots+A_{i}$ for $i=1,2, \ldots, k-1$, and $\mathrm{P}=-I+A_{1}+$ $A_{2}+\ldots+A_{k}$.

In order to fully investigate the long-run relationship among variables during our samples period selected, we incorporate two dummies, taking into account two 
financial shocks of the stock crash of the United States in 1997 (D97) and the Asian financial crisis (DAC), into our model.

$$
\Delta Y_{t}=\Gamma_{1} \Delta Y_{t-1}+\Gamma_{2} \Delta Y_{t-2}+\ldots+\Gamma_{k-1} \Delta Y_{t-(k-1)}+\Pi Y_{t-1}+\gamma_{1} D 97+\gamma_{2} D A C+\mu+\varepsilon_{t}
$$

The $\Pi$ matrix conveys information about the long-run relationship among elements of $Y_{t}$, and the rank of $\Pi$ is the number of linearly independent and stationary linear combinations of stock price series studied. Thus, testing for cointegration involves testing for the rank of $\Pi$ matrix, $r$, by examining whether the eigenvalues of $\Pi$ are significantly different from zero.

Johansen (1988) and Johansen and Juselius (1990) propose two test statistics for testing the number of cointegrating vetror (or the rank of $\Pi$ namely the trace and the maximum eigenvalue statistics. It is known that the cointegration tests are very sensitive to the choice of lag length. Since the estimation might be biased if the lag length is pre-designated without rigorous determination, this paper adopts Schwartz Bayesian information criterion (SBC) to determine the optimal number of lags based on the "principle of parsimony". The SBC suggests four lags for our six-market VAR model. The results of Table 3 presents the results from the Johansen (1988) and Johansen and Juselius's (1990) multivariate cointegration tests. Trace statistics and L-max statistics both suggest that there exists one cointegrating vector among these six stock markets, which implies that there exists a long-run relationship among these six stock markets. The existence of a long-run relationship among these six stock markets suggests that the long-run benefits for a Taiwan investor who diversifies in the stock markets of its major trading partners, namely those of Hong Kong, Japan Singapore, South Korea and the United States are not obtainable. Our finding of cointegration is quite compatible with the findings of Hassan and Naka (1996) and Masih and Masih (1997a).

To gain further insight these relationships, we also run cointegration tests by taking five markets, four markets, three markets and two markets at each time. The results from Panel B to Panel E of Table 3 show that there exists one cointegrating relationship among Taiwan-Japan-Hong Kong-South KoreaSingapore markets, Taiwan-Japan-US-South Korea-Singapore markets, TaiwanHong Kong-US-South Korea-Singapore markets (in terms of five-market models), Taiwan-Japan-South Korea-Singapore markets, Taiwan-Hong Kong-South KoreaSingapore markets, Taiwan-US-South Korea-Singapore markets (in terms of fourmarket models), and Taiwan-South Korea-Singapore markets (for three-market models). These results indicate that any portfolios regarding the above cases may 
not yield any international portfolio diversification in the long-run. However, there exists no cointegrating relationship among the rest of the market portfolios, which argue that there are gains from portfolio diversification in the long run for the rest of market portfolios.

The results above show that the dropping of either Singapore or South Korea markets from the market portfolios may lead to a rejection of cointegration and hence thus gain from diversification. These results suggest that analysis of more extensive portfolios and the drawing of conclusions regarding portfolio diversification must be carried out with great care for Taiwan investors. Pane F of Table 3 reports there exists strong cointegrating relationship between the stock markets of Singapore and South Korea. This further confirms our empirical findings. ${ }^{3}$

Table 3. Johansen and Jueslius's tests for multiple cointegrating vectors

\begin{tabular}{|c|c|c|c|c|}
\hline \multicolumn{5}{|c|}{$\begin{array}{l}\text { Panel A: Six-market model: } \\
\text { ingapore, South Korea, and the United States (VAR lag =4) }\end{array}$} \\
\hline & Trace test & L-max test & CV(Trace) & $\mathrm{CV}(\mathrm{L}-\max )$ \\
\hline $\mathrm{H}_{0}: \mathrm{r}=0$ & $94.97 *$ & $45.37 *$ & 94.15 & 39.37 \\
\hline $\mathrm{H}_{0}: \mathrm{r} \leq 1$ & 49.61 & 19.69 & 68.52 & 33.46 \\
\hline $\mathrm{H}_{0}: \mathrm{r} \leq 2$ & 29.92 & 14.71 & 47.21 & 27.07 \\
\hline $\mathrm{H}_{0}: \mathrm{r} \leq 3$ & 15.21 & 6.58 & 29.68 & 20.97 \\
\hline $\mathrm{H}_{0}: \mathrm{r} \leq 4$ & 8.63 & 5.18 & 15.41 & 14.07 \\
\hline $\mathrm{H}_{0}: \mathrm{r} \leq 5$ & 3.44 & 3.44 & 3.76 & 3.76 \\
\hline \multicolumn{5}{|c|}{ Panel B: Five-market models: } \\
\hline & Trace test & L-max test & CV(Trace) & $\mathrm{CV}(\mathrm{L}-\mathrm{max})$ \\
\hline $\mathrm{H}_{0}: \mathrm{r}=0$ & 51.84 & 21.37 & 68.52 & 33.46 \\
\hline $\mathrm{H}_{0}: \mathrm{r} \leq 1$ & 30.47 & 15.28 & 47.21 & 27.07 \\
\hline $\mathrm{H}_{0}: \mathrm{r} \leq 2$ & 15.18 & 7.15 & 29.68 & 20.97 \\
\hline $\mathrm{H}_{0}: \mathrm{r} \leq 3$ & 8.03 & 5.41 & 15.41 & 14.07 \\
\hline $\mathrm{H}_{0}: \mathrm{r} \leq 4$ & 2.62 & 2.62 & 3.76 & 3.76 \\
\hline
\end{tabular}

${ }^{3}$ In order to further verify our results, we also employ the Gregory and Hansen's (1996, Residual-based tests for cointegration in models with regime shifts, Journal of Econometrics, 70, 99-126) method to test the cointegrating relationship among the markets and the results are similar to those found in our earlier study indicating that there exists a long-term equilibrium relationship among markets with both South Korea and Singapore in the portfolios. 


\begin{tabular}{ccccc}
\hline \multicolumn{5}{c}{ Taiwan, Japan, Hong Kong, US, and singapore (VAR lag =6) } \\
\hline & Trace test & L-max test & CV(Trace) & CV(L-max) \\
\hline $\mathrm{H}_{0}: \mathrm{r}=0$ & 61.52 & 22.13 & 68.52 & 33.46 \\
$\mathrm{H}_{0}: \mathrm{r} \leq 1$ & 25.33 & 15.18 & 47.21 & 27.07 \\
$\mathrm{H}_{0}: \mathrm{r} \leq 2$ & 14.49 & 7.02 & 29.68 & 20.97 \\
$\mathrm{H}_{0}: \mathrm{r} \leq 3$ & 7.00 & 6.45 & 15.41 & 14.07 \\
$\mathrm{H}_{0}: \mathrm{r} \leq 4$ & 1.77 & 3.07 & 3.76 & 3.76 \\
\hline
\end{tabular}

\begin{tabular}{ccccc}
$\mathrm{H}_{0}: \mathrm{r} \leq 4$ & 2.05 & 2.05 & 3.76 & 3.76 \\
\hline \multicolumn{5}{c}{ Panel C: Four-market models: } \\
& \multicolumn{5}{c}{ Taiwan, Japan, Hong Kong, and Singapore (VAR lag = 6) } \\
\hline $\mathrm{H}_{0}: \mathrm{r}=0$ & \multicolumn{1}{c}{ Trace test } & L-max test & CV(Trace) & CV(L-max) \\
$\mathrm{H}_{0}: \mathrm{r} \leq 1$ & 38.17 & 16.61 & 47.21 & 27.07 \\
$\mathrm{H}_{0}: \mathrm{r} \leq 2$ & 21.56 & 11.17 & 29.68 & 20.97 \\
$\mathrm{H}_{0}: \mathrm{r} \leq 3$ & 10.39 & 7.05 & 15.41 & 14.07 \\
\hline \multicolumn{5}{c}{ Taiwan, Japan, Hong Kong, and South Korea (VAR lag =6) } \\
\hline $\mathrm{H}_{0}: \mathrm{r}=0$ & Trace test & L-max test & CV(Trace) & CV(L-max) \\
$\mathrm{H}_{0}: \mathrm{r} \leq 1$ & 32.37 & 17.48 & 47.21 & 27.07 \\
$\mathrm{H}_{0}: \mathrm{r} \leq 2$ & 14.88 & 6.15 & 29.68 & 20.97 \\
$\mathrm{H}_{0}: \mathrm{r} \leq 3$ & 8.74 & 5.36 & 15.41 & 14.07 \\
\hline
\end{tabular}


Long-Run Gains From International Equity Diversification:Taiwan's Evidence, 1995-2001 539

\begin{tabular}{|c|c|c|c|c|}
\hline \multicolumn{5}{|c|}{ Taiwan, Japan, Hong Kong, and US (VAR lag = 6) } \\
\hline & Trace test & L-max test & CV(Trace) & CV(L-max) \\
\hline $\mathrm{H}_{0}: \mathrm{r}=0$ & 40.32 & 19.84 & 47.21 & 27.07 \\
\hline $\mathrm{H}_{0}: \mathrm{r} \leq 1$ & 20.48 & 13.49 & 29.68 & 20.97 \\
\hline $\mathrm{H}_{0}: \mathrm{r} \leq 2$ & 7.00 & 5.24 & 15.41 & 14.07 \\
\hline $\mathrm{H}_{0}: \mathrm{r} \leq 3$ & 1.76 & 1.76 & 3.76 & 3.76 \\
\hline \multicolumn{5}{|c|}{ Taiwan, Japan, US and South Korea (VAR lag = 6) } \\
\hline & Trace test & L-max test & CV(Trace) & CV(L-max) \\
\hline $\mathrm{H}_{0}: \mathrm{r}=0$ & 31.72 & 15.18 & 47.21 & 27.07 \\
\hline $\mathrm{H}_{0}: \mathrm{r} \leq 1$ & 16.55 & 7.02 & 29.68 & 20.97 \\
\hline $\mathrm{H}_{0}: \mathrm{r} \leq 2$ & 9.53 & 6.45 & 15.41 & 14.07 \\
\hline $\mathrm{H}_{0}: \mathrm{r} \leq 3$ & 3.08 & 3.07 & 3.76 & 3.76 \\
\hline \multicolumn{5}{|c|}{ Taiwan, Japan, US and Singapore (VAR lag =6) } \\
\hline & Trace test & L-max test & CV(Trace) & CV(L-max) \\
\hline $\mathrm{H}_{0}: \mathrm{r}=0$ & 32.99 & 13.73 & 47.21 & 27.07 \\
\hline $\mathrm{H}_{0}: \mathrm{r} \leq 1$ & 19.27 & 11.62 & 29.68 & 20.97 \\
\hline $\mathrm{H}_{0}: \mathrm{r} \leq 2$ & 7.65 & 5.31 & 15.41 & 14.07 \\
\hline $\mathrm{H}_{0}: \mathrm{r} \leq 3$ & 2.34 & 2.34 & 3.76 & 3.76 \\
\hline \multicolumn{5}{|c|}{ Taiwan, Japan, Singapore and South Korea (VAR lag =6) } \\
\hline & Trace test & L-max test & CV(Trace) & CV(L-max) \\
\hline $\mathrm{H}_{0}: \mathrm{r}=0$ & $49.71 *$ & $34.40^{*}$ & 47.21 & 27.07 \\
\hline $\mathrm{H}_{0}: \mathrm{r} \leq 1$ & 15.31 & 7.15 & 29.68 & 20.97 \\
\hline $\mathrm{H}_{0}: \mathrm{r} \leq 2$ & 8.16 & 4.47 & 15.41 & 14.07 \\
\hline $\mathrm{H}_{0}: \mathrm{r} \leq 3$ & 3.67 & 3.67 & 3.76 & 3.76 \\
\hline \multicolumn{5}{|c|}{ Taiwan, Hong Kong, US, and South Korea (VAR lag = 6) } \\
\hline & Trace test & L-max test & CV(Trace) & CV(L-max) \\
\hline $\mathrm{H}_{0}: \mathrm{r}=0$ & 33.19 & 20.14 & 47.21 & 27.07 \\
\hline $\mathrm{H}_{0}: \mathrm{r} \leq 1$ & 13.06 & 5.95 & 29.68 & 20.97 \\
\hline $\mathrm{H}_{0}: \mathrm{r} \leq 2$ & 7.11 & 4.61 & 15.41 & 14.07 \\
\hline $\mathrm{H}_{0}: \mathrm{r} \leq 3$ & 1.77 & 3.07 & 3.76 & 3.76 \\
\hline \multicolumn{5}{|c|}{ Taiwan, Hong Kong, US, and Singapore (VAR lag = 6) } \\
\hline & Trace test & L-max test & CV(Trace) & CV(L-max) \\
\hline $\mathrm{H}_{0}: \mathrm{r}=0$ & 42.28 & 20.14 & 47.21 & 27.07 \\
\hline $\mathrm{H}_{0}: \mathrm{r} \leq 1$ & 22.66 & 12.21 & 29.68 & 20.97 \\
\hline $\mathrm{H}_{0}: \mathrm{r} \leq 2$ & 10.46 & 7.71 & 15.41 & 14.07 \\
\hline $\mathrm{H}_{0}: \mathrm{r} \leq 3$ & 2.75 & 2.75 & 3.76 & 3.76 \\
\hline \multicolumn{5}{|c|}{ Taiwan, Hong Kong, Singapore and South Korea (VAR lag = 6) } \\
\hline & Trace test & L-max test & CV(Trace) & CV(L-max) \\
\hline $\mathrm{H}_{0}: \mathrm{r}=0$ & $64.74^{*}$ & $43.90^{*}$ & 47.21 & 27.07 \\
\hline $\mathrm{H}_{0}: \mathrm{r} \leq 1$ & 20.85 & 14.26 & 29.68 & 20.97 \\
\hline $\mathrm{H}_{0}: \mathrm{r} \leq 2$ & 6.59 & 4.76 & 15.41 & 14.07 \\
\hline $\mathrm{H}_{0}: \mathrm{r} \leq 3$ & 1.82 & 1.82 & 3.76 & 3.76 \\
\hline
\end{tabular}




\begin{tabular}{ccccc}
\hline \multicolumn{5}{c}{ Taiwan, US, Singapore and South Korea (VAR lag = 6) } \\
\hline & Trace test & L-max test & CV(Trace) & CV(L-max) \\
\hline $\mathrm{H}_{0}: \mathrm{r}=0$ & $53.29^{*}$ & $38.97^{*}$ & 47.21 & 27.07 \\
$\mathrm{H}_{0}: \mathrm{r} \leq 1$ & 14.32 & 5.73 & 29.68 & 20.97 \\
$\mathrm{H}_{0}: \mathrm{r} \leq 2$ & 8.59 & 4.62 & 15.41 & 14.07 \\
$\mathrm{H}_{0}: \mathrm{r} \leq 3$ & 3.17 & 3.17 & 3.76 & 3.76 \\
\hline
\end{tabular}

Panel D: Three-market models:

Taiwan, Japan, and Hong Kong (VAR lag = 8)

\begin{tabular}{|c|c|c|c|c|}
\hline & Trace test & L-max test & CV(Trace) & CV(L-max) \\
\hline $\mathrm{H}_{0}: \mathrm{r}=0$ & 22.14 & 14.48 & 29.68 & 20.97 \\
\hline $\mathrm{H}_{0}: \mathrm{r} \leq 1$ & 7.65 & 5.34 & 15.41 & 14.07 \\
\hline $\mathrm{H}_{0}: \mathrm{r} \leq 2$ & 2.31 & 2.31 & 3.76 & 3.76 \\
\hline \multicolumn{5}{|c|}{ Taiwan, Japan, and Singaore $\quad($ VAR lag $=8)$} \\
\hline & Trace test & L-max test & CV(Trace) & CV(L-max) \\
\hline $\mathrm{H}_{0}: \mathrm{r}=0$ & 20.74 & 11.67 & 29.68 & 20.97 \\
\hline $\mathrm{H}_{0}: \mathrm{r} \leq 1$ & 9.07 & 5.40 & 15.41 & 14.07 \\
\hline $\mathrm{H}_{0}: \mathrm{r} \leq 2$ & 3.65 & 3.65 & 3.76 & 3.76 \\
\hline \multicolumn{5}{|c|}{ Taiwan, Japan, and South Korea (VAR lag = 9) } \\
\hline & Trace test & L-max test & CV(Trace) & CV(L-max) \\
\hline $\mathrm{H}_{0}: \mathrm{r}=0$ & 20.65 & 11.64 & 29.68 & 20.97 \\
\hline $\mathrm{H}_{0}: \mathrm{r} \leq 1$ & 9.00 & 9.39 & 15.41 & 14.07 \\
\hline $\mathrm{H}_{0}: \mathrm{r} \leq 2$ & 3.66 & 3.66 & 3.76 & 3.76 \\
\hline \multicolumn{5}{|c|}{ Taiwan, Japan, and US (VAR lag = 8) } \\
\hline & Trace test & L-max test & CV(Trace) & CV(L-max) \\
\hline $\mathrm{H}_{0}: \mathrm{r}=0$ & 22.28 & 13.09 & 29.68 & 20.97 \\
\hline $\mathrm{H}_{0}: \mathrm{r} \leq 1$ & 9.19 & 6.29 & 15.41 & 14.07 \\
\hline $\mathrm{H}_{0}: \mathrm{r} \leq 2$ & 2.90 & 2.90 & 3.76 & 3.76 \\
\hline \multicolumn{5}{|c|}{ Taiwan, Hong Kong, and Singapore (VAR lag = 8) } \\
\hline & Trace test & L-max test & CV(Trace) & CV(L-max) \\
\hline $\mathrm{H}_{0}: \mathrm{r}=0$ & 23.75 & 12.59 & 29.68 & 20.97 \\
\hline $\mathrm{H}_{0}: \mathrm{r} \leq 1$ & 11.15 & 9.41 & 15.41 & 14.07 \\
\hline $\mathrm{H}_{0}: \mathrm{r} \leq 2$ & 1.74 & 1.74 & 3.76 & 3.76 \\
\hline \multicolumn{5}{|c|}{ Taiwan, Hong Kong, South Korea (VAR lag = 8) } \\
\hline & Trace test & L-max test & CV(Trace) & CV(L-max) \\
\hline $\mathrm{H}_{0}: \mathrm{r}=0$ & 15.89 & 7.83 & 29.68 & 20.97 \\
\hline $\mathrm{H}_{0}: \mathrm{r} \leq 1$ & 8.07 & 5.09 & 15.41 & 14.07 \\
\hline $\mathrm{H}_{0}: \mathrm{r} \leq 2$ & 2.98 & 2.98 & 3.76 & 3.76 \\
\hline \multicolumn{5}{|c|}{ Taiwan, Hong Kong, and US (VAR lag = 8) } \\
\hline & Trace test & L-max test & CV(Trace) & CV(L-max) \\
\hline $\mathrm{H}_{0}: \mathrm{r}=0$ & 25.28 & 16.95 & 29.68 & 20.97 \\
\hline $\mathrm{H}_{0}: \mathrm{r} \leq 1$ & 8.33 & 5.14 & 15.41 & 14.07 \\
\hline $\mathrm{H}_{0}: \mathrm{r} \leq 2$ & 3.19 & 3.19 & 3.76 & 3.76 \\
\hline
\end{tabular}


Long-Run Gains From International Equity Diversification:Taiwan's Evidence, 1995-2001 541

\begin{tabular}{|c|c|c|c|c|}
\hline \multicolumn{5}{|c|}{ Taiwan, US and, Singapore (VAR lag = 8) } \\
\hline & Trace test & L-max test & CV(Trace) & CV(L-max) \\
\hline $\mathrm{H}_{0}: \mathrm{r}=0$ & 19.47 & 10.28 & 29.68 & 20.97 \\
\hline $\mathrm{H}_{0}: \mathrm{r} \leq 1$ & 9.19 & 5.57 & 15.41 & 14.07 \\
\hline $\mathrm{H}_{0}: \mathrm{r} \leq 2$ & 3.62 & 3.62 & 3.76 & 3.76 \\
\hline \multicolumn{5}{|c|}{ Taiwan, US and, South Korea (VAR lag = 8) } \\
\hline & Trace test & L-max test & CV(Trace) & CV(L-max) \\
\hline $\mathrm{H}_{0}: \mathrm{r}=0$ & 14.63 & 6.18 & 29.68 & 20.97 \\
\hline $\mathrm{H}_{0}: \mathrm{r} \leq 1$ & 8.54 & 5.62 & 15.41 & 14.07 \\
\hline $\mathrm{H}_{0}: \mathrm{r} \leq 2$ & 2.83 & 2.83 & 3.76 & 3.76 \\
\hline \multicolumn{5}{|c|}{ Taiwan, Singapore, and South Korea (VAR lag = 8) } \\
\hline & Trace test & L-max test & CV(Trace) & CV(L-max) \\
\hline $\mathrm{H}_{0}: \mathrm{r}=0$ & $34.69^{*}$ & $26.78^{*}$ & 29.68 & 20.97 \\
\hline $\mathrm{H}_{0}: \mathrm{r} \leq 1$ & 7.92 & 4.98 & 15.41 & 14.07 \\
\hline $\mathrm{H}_{0}: \mathrm{r} \leq 2$ & 2.93 & 2.93 & 3.76 & 3.76 \\
\hline \multicolumn{5}{|c|}{ Panel E: Two-market models: Taiwan and Japan (VAR lag = 4) } \\
\hline & Trace test & L-max test & CV(Trace) & CV(L-max) \\
\hline $\mathrm{H}_{0}: \mathrm{r}=0$ & 9.95 & 6.33 & 15.41 & 14.07 \\
\hline $\mathrm{H}_{0}: \mathrm{r} \leq 1$ & 3.62 & 3.62 & 3.76 & 3.76 \\
\hline \multicolumn{5}{|c|}{ Taiwan and Hong Kong (VAR lag = 4) } \\
\hline & Trace test & L-max test & CV(Trace) & CV(L-max) \\
\hline $\mathrm{H}_{0}: \mathrm{r}=0$ & 11.87 & 8.97 & 15.41 & 14.07 \\
\hline $\mathrm{H}_{0}: \mathrm{r} \leq 1$ & 2.90 & 2.90 & 3.76 & 3.76 \\
\hline \multicolumn{5}{|c|}{ Taiwan and Singapore (VAR lag = 4) } \\
\hline & Trace test & L-max test & CV(Trace) & $\mathrm{CV}(\mathrm{L}-\mathrm{max})$ \\
\hline $\mathrm{H}_{0}: \mathrm{r}=0$ & 10.79 & 7.39 & 15.41 & 14.07 \\
\hline $\mathrm{H}_{0}: \mathrm{r} \leq 1$ & 3.40 & 3.40 & 3.76 & 3.76 \\
\hline \multicolumn{5}{|c|}{ Taiwan and South Korea (VAR lag = 4) } \\
\hline & Trace test & L-max test & CV(Trace) & CV(L-max) \\
\hline $\mathrm{H}_{0}: \mathrm{r}=0$ & 7.53 & 4.60 & 15.41 & 14.07 \\
\hline $\mathrm{H}_{0}: \mathrm{r} \leq 1$ & 2.92 & 2.92 & 3.76 & 3.76 \\
\hline \multicolumn{5}{|c|}{ Taiwan and US (VAR lag $=21)$} \\
\hline & Trace test & L-max test & CV(Trace) & CV(L-max) \\
\hline $\mathrm{H}_{0}: \mathrm{r}=0$ & 8.39 & 5.14 & 15.41 & 14.07 \\
\hline $\mathrm{H}_{0}: \mathrm{r} \leq 1$ & 3.25 & 3.25 & 3.76 & 3.76 \\
\hline \multicolumn{5}{|c|}{ Panel F: Singapore and South Korea (VAR lag = 4) } \\
\hline & Trace test & L-max test & CV(Trace) & CV(L-max) \\
\hline $\mathrm{H}_{0}: \mathrm{r}=0$ & $27.02 *$ & $23.42 *$ & 15.41 & 14.07 \\
\hline $\mathrm{H}_{0}: \mathrm{r} \leq 1$ & 3.60 & 1.67 & 3.76 & 3.76 \\
\hline
\end{tabular}

Note: $1 . \mathrm{CV}$ is the abbreviation for the critical value.

2. Critical values are taken from Osterwald-Lenum (1992).

3. * indicates significance at the $5 \%$ level.

4. Schwartz Bayesian information criteria (SBC), is used to select the number of lags required in the cointegrating test. The computed Ljung-Box Q-statistics also indicate that the residuals are white noise. The Lagrange multiplier test also indicates no evidence of ARCH effects in systems. 


\section{Conclusion}

This study provides evidence that there exist no potential long-run portfolio diversification gains to Taiwan investors from diversifying in the stock markets of its major trading partners, namely those of Hong Kong, Japan, Singapore, South Korea, and the United States, in the sense that there is evidence of cointegrating relationship among these stock markets. However, our results show that the dropping of both Singapore and South Korea markets from the market portfolio may lead to a rejection of cointegration and hence imply gains from diversification. Our results argue that the analysis of more extensive portfolios and the drawing of conclusions regarding portfolio diversification must be carried out with great care for Taiwan investors. These findings can be valuable to Taiwan individual investors and financial institutions evaluating international portfolios, as well as institutions such as superannuation funds holding internationally diversified long-run investment portfolios.

Received January 2002, Accepted 27 January 2003

\section{References}

Arshanapalli, B., and Doukas. J. (1993), "International stock market linkages: Evidence from the pre- and post-October 1987 period," Journal of Banking and Finance, 93-208.

Arshanapalli, B., Doukas, J., and Lang, Larry H. P. (1995), "Pre and post-October 1987 stock market linkages between U.S. and Asian markets," Pacific-Basin Finance Journal, 3, 57-73.

Bierens, H. J. (1997), "Nonparametric cointegration analysis," Journal of Econometrics, 77, 379-404.

Campbell, J. and Perron, Peter. (1991), "What macroeconomists should know about unit roots, edited by O. Blanchard and S. Fisher," NBER macroeconomics annual, MIT Press, Cambridge, MA.

Chan, K.C., Gup, B. E., and Pan, M. S. (1992), "An empirical analysis of stock prices in major Asian markets and the United States," The Financial Review, 27, 289-308.

Chowdhury, Abdur R. (1994), "Stock market interdependencies: evidence from the Asian NIEs," Journal of Macroeconomics, 16, 4, 629-651.

Dickey, David. A. and Fuller, W. A. (1981), "Likelihood ratio statistics for autoregressive time series with a unit root," Econometrica, 49, 4, 1057-1072.

Engle, Robert F. and Granger, C. W. J. (1987), "Co-integration and error correction: representation, estimation and testing," Econometrica, 55, 251-276.

Gonzalo, Jesus (1994), "Five alternative methods of estimating long-run equilibrium 
Long-Run Gains From International Equity Diversification:Taiwan's Evidence, 1995-2001 543

relationships," Journal of Econometrics, 203-233.

Gregory, A.W. and Hansen, B E. (1996) Residual-based tests for cointegration in models with regime shifts, Journal of Econometrics, 70, 99-126.

Granger, C. W. J. (1981), "Some Properties of Time Series Data and Their Use in Econometric Model Specification," Journal of Economics, 16, 121-130.

Hassan, M. Kabir. and Naka, Atsuyuki. (1996), "Short-run and long-run dynamic linkages among international stock markets," International Review of Economics and Finance, 5, 4, 387-405.

Johansen, S. (1988), "Statistical analysis of cointegration vectors," Journal of Economics Dynamic and Control, 12, 231-254.

Johansen, S. and Juselius, K. (1990), "Maximum likelihood estimation and inference on cointegration - with application to the demand for money," Oxford Bulletin of Economics and Statistics, 2, 169-210.

Kanas, Angelos. (1998), "Linkages between the US and European equity markets: further evidence from cointegration tests," Applied Financial Economics, 8, 607-614.

Kremers, J.M., Erisccos, N.R., and Dolado, J. J. (1992), "The power of cointegration tests, Oxford Bulletin of Economics and Statistics 54, 325-346.

Kwan, Andy C. C., Sim, Ah-Boon and Cotsomitis, John A. (1995), "The Causal relationships between equity indices on world exchanges," Applied Economics, 27, 33-37.

Lee, Bong-Soo and Jeon, Bang Nam. (1995), "Common stochastic trends and predictability of international stock prices," Journal of the Japanese and International Economics, 9, 245-277.

Mackinnon, James. (1991), Critical values for cointegration tests in long-run economic relationships - Readings in Cointegration, edited by Engle and Granger, Oxford University Press.

Masih, A. M. M. and Masih, R. (1997a), “A comparative analysis of the propagation of stock market fluctuations in alternative models of dynamic causal linkages," Applied Financial Economics, 7(1), pp.59-74

, (1997b), "Dynamic Linkages and the Propagation Mechanism Driving Major International Stock Markets: An Analysis of the Pre- and Post-Crash Eras," The Quarterly Review of Economics and Finance, 37(4), 859-885

McDonald, R. and Taylor, M. (1989), "Foreign exchange market efficiency and cointegration: some evidence from the recent float," Economic Letters, 29, 63-68.

Nelson, Charles R and Plosser, Charles I. (1982), "Trends and random walks in macroeconomic time series," Journal of Monetary Economics, 10, 139-162.

Newey, W. K., and West, K. D. (1987), "A simple, positive semi-definite heteroskedasticity and autocorrelation consistent covariance matrix," Econometrica, 3, 703-708.

Osterwald-Lenum, M. (1992), "A note with fractiles of the asymptotic distribution of the likelihood cointegration rank test statistics," Oxford Bulletin of Economics and Statistics, 54, 889-895. 
Phillips, P. C. and Perron, P. (1988), "Testing for a unit root in time series regression," Biometrika, 75, 335-346.

Phillips, P. C. and Ouliaris, S. (1990), "Asymptotic propertities of residuals based tests for cointegration," Econometrics, 58, 165-193.

Roger, John H. (1994), "Entry barriers and price movements between major and emerging stock markets," Journal of Macroeconomics, 16, 2, 221-241. 


\title{
Long-Run Gains From International Equity Diversification: Taiwan's Evidence, 1995-2001
}

\author{
Chien-Chung Neih \\ Tamkang University \\ Tsangyao Chang \\ Feng Chia University
}

\begin{abstract}
This study attempts to explore whether there exist long-run gains from international equity diversification for Taiwan investors who invest in the stock markets of its major trading partners, namely those of Hong Kong, Japan, Singapore, South Korea, and the United States. We further incorporate two dummies, taking into account two financial shocks of the stock crash of the United States in 1997 (D97) and the Asian financial crisis (DAC), into our model. The results indicate that these six stock markets are cointegrated with one cointegrating vector, which implies that the efficient market hypothesis (EMH) is violated in this multinational stock markets and the Taiwan investors may not benefit from portfolio diversification in the stock markets of its major trading partners. However, the dropping of either Singapore or South Korea markets from the portfolios leads to a rejection of cointegration and hence implies gains from diversification. Our results argue that analysis of more extensive investment portfolios and the drawing of conclusions regarding portfolio diversification must be carried out with great care for Taiwan investors.
\end{abstract}

- JEL Classifications: C32, F21

\footnotetext{
*Corresponding address: Professor Chien-Chung Nieh, Tamkang University, Department and Graduate Institute of Banking and Finance, Tamsui, 251, Taipei Hsien, Taiwan, ROC. Tel: $+886-2-26215656$ ext.2591, Fax: +886-2-26214755, E-mail: niehcc@mail.tku.edu.tw Professor Tsangyao Chang FengChia University, Department and Graduate Institute of Economics, Taichung, Taiwan. Tel: +886-424517250 ext.4484, E-mail: tychang@fcu.edu.tw.

(C2003-Center for International Economics, Sejong Institution, All Rights Reserved.
} 
- Key words: Long-run gains, Stock market, Equity diversification, Cointegration, Efficient market hypothesis

\section{Introduction}

Over the past two decades a vast amount of research has been devoted to studying the interdependence among national equity markets, especially in the wake of the October 1987 crash which caused correlated stock price movements across international stock markets. ${ }^{1}$ Previous empirical studies have employed cointegration techniques to explore international equity market linkages. The study of MacDonald and Taylor (1989) argues that asset prices from two different efficient markets cannot be cointegrated. Specifically, if a pair of stock prices is cointegrated, one stock price can be forecast (is Granger-caused) by the other. Thus, cointegration is inconsistent with weak form efficiency. These cointegration results suggest that there are no gains from portfolio diversification.

Most studies are centralized in examining the long-run gains for the investors of the large industrialized countries. For example, potential long-run benefits from international diversification between the U.S. and Japan, and the stock markets in French, German and the UK during the pre and post October crash are found in Arshanapalli and Doukas (1993). Which examining the linkages and dynamic interactions among five stock markets using pairwise cointegration and errorcorrection models. Same conclusions of the existence of potential long-run benefits in risk reduction from diversifying in US stocks and stocks in any of the major European markets are found in Kanas (1998). ${ }^{2}$ In contrast to Arshanapalli and Doukas (1993) and Kanas (1998), this result of Hassan and Naka (1996) suggests that the benefits from international diversification among the U.S., Japan, U.K. and Germany stock markets are not obtainable. Hassan and Naka (1996) investigated the dynamic linkages among the U.S., Japan, U.K. and German stock market indices using multivariate cointegration and error-correction models and significantly found that both short-run and long-run relationships among these

${ }^{1}$ Literature investigating the effect of 1987 stock crash on the linkage among international equities can be found in Arshanapalli and Doukas (1993), Arshanapalli, Doukas and Lang (1995) and Masih and Masih (1997b)

${ }^{2}$ Kanas (1998) employed the Phillips and Ouliaris's (1990) multivariate trace statistic, the Johansen methods, and the recently proposed Bierens's (1997) nonparametric approach to test for pairwise cointegration between the US and six largest European equity markets. 
four industrialized countries' stock indices are existed.

Recently, considerable attention has been given to possible linkages and interdependencies in major Asian countries. Chan, Gup and Pan (1992), Chowdhury (1994), Roger (1994) and Kwan, Erisccos and Dolado (1995), using cointegration tests and vector autoregressive analysis, report that international diversification in major countries are effective. Arshanapalli, Doukas and Lang (1995) examine the links and dynamic interactions between the U.S. and six major Asian stock markets before and after October 1987 and find a long-run equilibrium relationship between the U.S. and Asian stock market movements during the post-October 1987 period. This result suggests that the benefits from international diversification between U.S. and the Asian equity markets have substantially reduced since October 1987. Masih and Masih (1997a) also tested for multivariate cointegration between four Asian Newly Industrializing Countries stock markets - Taiwan, South Korea, Singapore, and Hong Kong - in models incorporating the established markets of the U.S., Japan, UK and Germany and reached the same conclusions.

The objective of this study is to explore whether there exist long-run gains from international equity diversification for Taiwan investors who invest in the equity markets of its major trading partners, namely those of Hong Kong, Japan, Singapore, South Korea and the United States over the period January 5, 1995 to February 16, 2001. The main reasons for us to chooses these five countries is that the share of exports and imports from Taiwan to these five countries were relatively high about $61.8 \%$ and $51.8 \%$, respectively, at the end of 1999. In order to fully investigate the long-run relationship among variables during our samples period selected, we incorporate two dummies, taking into account two financial shocks of the stock crash of the United States in 1997 (D97) and the Asian financial crisis (DAC), into our model. We explore the potential for long-run diversification gains for Taiwan investors by examining whether Taiwan market is multivariated cointegrated with the stock markets of the Hong Kong, Japan, Singapore, South Korea and the United States. The results from Johansen (1988) and Johansen and Juselius's (1990) multivariate cointegration test indicate that these six stock markets are cointegrated with one cointegrating vector. This implicates that the efficient market hypothesis (EMH) is violated in this multivariate context and the Taiwan investors may not yield portfolio diversification from these countries in the long run. However, the dropping of either Singapore or South Korea markets from the portfolios leads to a rejection of 
cointegration and hence implies gains from portfolio diversification. Our results suggest that analysis of more extensive investment portfolios and the drawing of conclusions regarding portfolio diversification must be carried out with great care for Taiwan investors over this sample period. These results are valuable to Taiwan individual investors and financial institutions holding internationally diversified long-run investment portfolios.

The major motivations for this study are several folds. First, Taiwan is a rapidly expanding emerging market and a significant number of Taiwan investors have adopted diversification benefits as the primary criterion in investing outside Taiwan. Second, the rapid growth of the Taiwan economy has attracted the attention of international investors and both Dow Jones and Morgan Stanley have put Taiwan stocks into their international indexes since September 1997. This suggests that the issue of international linkages of the Taiwan share market is of practical interest to a significant number of international investors. Third, little evidence is available on the long-run linkages of Taiwan share markets and its implications for long-run benefits from international equity diversification.

The remainder of this study is organized as follows. Section II presents the data used. Section III presents the methodologies used and discusses the empirical results. Finally, Section IV concludes.

\section{Data}

Our empirical analysis employs daily data on stock price indexes for Taiwan and its major trading partners, namely those of Japan, Hong Kong, Singapore, South Korea, and the United States over the period of January 5, 1995 to February 16, 2001. The representative indexes used in the analysis are shown in Table 1. The daily closing price index data are collected from the Taiwan Stock Exchange and the AREMOS of the Ministry of Education, Taiwan. All the indexes are based on local currencies. Following the Chowdhury's (1994) study, the time series data have been adjusted by dropping some entries, including the Saturday entries, to guarantee that each country has an entry on given date. According to Chowdhury (1994), this method may take care of data gap caused by holidays and other nonworking days. Therefore, the total number of observations for each country is 1247. All series are measured in natural logs. Causal observation suggests that each stock price series appears to be nonstationary and that these six national stock price indexes tend to move more or less together over time, a result 
Table 1. The Representative Stock Price Indexes

\begin{tabular}{ll}
\hline Country & \multicolumn{1}{c}{ Stock Index } \\
\hline Taiwan & Weighted Index \\
Hong Kong & Heng Seng Index \\
Japan & Nikkei Stock Average \\
Singapore & Strait Index \\
South Korea & Composite Index \\
USA & Dow Jones Industrial Index \\
\hline
\end{tabular}

which is later confirmed through the use of cointegration technique.

\section{Methodology and Empirical Results}

\section{A. Unit Root Tests of National Stock Price Indices}

Recent studies have found that many macroeconomic and financial time series, including stock price series, contain unit roots dominated by stochastic trends (see Nelson and Plosser, 1982; Lee and Jeon, 1995). A necessary but not sufficient

Table 2. Unit Root Tests for individual stock price indices:

(January 5, 1995 to Feburary 16, 2001)

\begin{tabular}{|c|c|c|}
\hline \multicolumn{2}{|c|}{ Panel A: Augmented Dickey-Fuller } & \multirow[t]{2}{*}{ Panel B: Phillips-Perron } \\
\hline \multicolumn{2}{|c|}{ Levels } & \\
\hline $\mathrm{TN}$ & $-1.516(4)$ & $-1.606[7]$ \\
\hline HK & -1.976 (4) & $-1.836[7]$ \\
\hline JP & $-1.389(4)$ & $-1.487[7]$ \\
\hline SP & $-1.529(4)$ & $-1.579[7]$ \\
\hline SK & $-1.623(4)$ & $-1.612[7]$ \\
\hline US & $-2.016(4)$ & $-1.980[7]$ \\
\hline \multicolumn{3}{|c|}{ First-differences } \\
\hline $\mathrm{TN}$ & $-15.737 *(4)$ & $-33.998 *[7]$ \\
\hline HK & $-15.657 *(4)$ & $-35.413 *[7]$ \\
\hline JP & $-16.164 *(4)$ & $-36.618^{*}[7]$ \\
\hline SP & $-14.781 *(4)$ & $-30.638 *[7]$ \\
\hline SK & $-16.470 *(4)$ & $-33.355 *[7]$ \\
\hline US & $-15.865^{*}(4)$ & $-35.476^{*}[7]$ \\
\hline
\end{tabular}

Note: 1 . The number in the parenthesis indicates the appropriate order of the ADF model.

Lags were chosen based on the Campbell and Perron's (1991), method.

2. The number in the bracket indicate the lag truncation for Bartlett kernel suggested by NeweyWest test (1987).

3. *indicates significance at $5 \%$ level. 
condition for cointegration is that each of the stock price index series should be integrated of the same order (or I(1), see Granger, 1981). In this study, unit root is tested using both Augmented Dickey-Fuller (ADF) (1981) and Phillips-Perron (PP) (1988) tests. Panel A in Table 2 reports the results of non-stationary tests for Taiwan, Hong Kong, Japan, Singapore, South Korea, and the U.S. stock price indexes using augmented Dickey-Fuller tests. According to the applicable test statistics reported by Mackinnon (1991), non-stationarity can not be rejected for the levels of each stock price series at the 5-percent significance level based on ADF test. In contrast, when the data are differenced, non-stationarity can be rejected for all data series. These results imply that each stock price index are integrated of order one (or I(1)). The forms of I(1) series for all the stock indices are further confirmed by the P-P test as shown in Pane B of Table 2.

\section{B. Cointegration Tests}

Given unit roots, the issue arises whether there exists some long-run equilibrium relationship among stock price indexes. The existence of long-run equilibrium relationship among variables is referred to literature as cointegration. According to Granger (1981), a vector of variables, $Y_{t}$ is said to be cointegrated of order $(\mathrm{d}, \mathrm{b})$ - denoted CI $(\mathrm{d}, \mathrm{b})$ - if all the elements of $Y_{t}$ are integrated of the same order $d$ and there exists a linear combination of these elements, which is integrated of order (d-b) (ie., I(d-b) with $b>0$ ). Cointegration tests in this study are conducted using the multivariate maximum likelihood methedology developed by Johansen (1988) and Johansen and Juselius (1990). This procedure is currently the most reliable test for cointegration and avoids the problems with the Engle and Granger's (1987) two-step procedure, as shown in Kremers, Erisccos and Dolado (1992) and in Gonzalo (1994).

Following Johansen (1988) and Johansen and Juselius (1990), we construct a pdimensional vector autoregressive model with Gaussian errors, expressed by its first-differenced error correction from as

$$
\Delta Y_{t}=\Gamma_{1} \Delta Y_{t-1}+\Gamma_{2} \Delta Y_{t-2} \ldots+\Gamma_{k-1} \Delta Y_{t-(k-1)}+\Pi Y_{t-1}+\psi D_{t}+\varepsilon_{t}
$$

where $Y_{t}$ is the vector of the national stock series studied; $\varepsilon_{t}$ is i.i.d. $\mathrm{N}(0, \Sigma)$,a white noise process; $\Gamma_{i}=-I+A_{1}+A_{2}+\ldots+A_{i}$ for $i=1,2, \ldots, k-1$, and $\mathrm{P}=-I+A_{1}+$ $A_{2}+\ldots+A_{k}$.

In order to fully investigate the long-run relationship among variables during our samples period selected, we incorporate two dummies, taking into account two 
financial shocks of the stock crash of the United States in 1997 (D97) and the Asian financial crisis (DAC), into our model.

$$
\Delta Y_{t}=\Gamma_{1} \Delta Y_{t-1}+\Gamma_{2} \Delta Y_{t-2}+\ldots+\Gamma_{k-1} \Delta Y_{t-(k-1)}+\Pi Y_{t-1}+\gamma_{1} D 97+\gamma_{2} D A C+\mu+\varepsilon_{t}
$$

The $\Pi$ matrix conveys information about the long-run relationship among elements of $Y_{t}$, and the rank of $\Pi$ is the number of linearly independent and stationary linear combinations of stock price series studied. Thus, testing for cointegration involves testing for the rank of $\Pi$ matrix, $r$, by examining whether the eigenvalues of $\Pi$ are significantly different from zero.

Johansen (1988) and Johansen and Juselius (1990) propose two test statistics for testing the number of cointegrating vetror (or the rank of $\Pi$ namely the trace and the maximum eigenvalue statistics. It is known that the cointegration tests are very sensitive to the choice of lag length. Since the estimation might be biased if the lag length is pre-designated without rigorous determination, this paper adopts Schwartz Bayesian information criterion (SBC) to determine the optimal number of lags based on the "principle of parsimony". The SBC suggests four lags for our six-market VAR model. The results of Table 3 presents the results from the Johansen (1988) and Johansen and Juselius's (1990) multivariate cointegration tests. Trace statistics and L-max statistics both suggest that there exists one cointegrating vector among these six stock markets, which implies that there exists a long-run relationship among these six stock markets. The existence of a long-run relationship among these six stock markets suggests that the long-run benefits for a Taiwan investor who diversifies in the stock markets of its major trading partners, namely those of Hong Kong, Japan Singapore, South Korea and the United States are not obtainable. Our finding of cointegration is quite compatible with the findings of Hassan and Naka (1996) and Masih and Masih (1997a).

To gain further insight these relationships, we also run cointegration tests by taking five markets, four markets, three markets and two markets at each time. The results from Panel B to Panel E of Table 3 show that there exists one cointegrating relationship among Taiwan-Japan-Hong Kong-South KoreaSingapore markets, Taiwan-Japan-US-South Korea-Singapore markets, TaiwanHong Kong-US-South Korea-Singapore markets (in terms of five-market models), Taiwan-Japan-South Korea-Singapore markets, Taiwan-Hong Kong-South KoreaSingapore markets, Taiwan-US-South Korea-Singapore markets (in terms of fourmarket models), and Taiwan-South Korea-Singapore markets (for three-market models). These results indicate that any portfolios regarding the above cases may 
not yield any international portfolio diversification in the long-run. However, there exists no cointegrating relationship among the rest of the market portfolios, which argue that there are gains from portfolio diversification in the long run for the rest of market portfolios.

The results above show that the dropping of either Singapore or South Korea markets from the market portfolios may lead to a rejection of cointegration and hence thus gain from diversification. These results suggest that analysis of more extensive portfolios and the drawing of conclusions regarding portfolio diversification must be carried out with great care for Taiwan investors. Pane F of Table 3 reports there exists strong cointegrating relationship between the stock markets of Singapore and South Korea. This further confirms our empirical findings. ${ }^{3}$

Table 3. Johansen and Jueslius's tests for multiple cointegrating vectors

\begin{tabular}{|c|c|c|c|c|}
\hline \multicolumn{5}{|c|}{$\begin{array}{l}\text { Panel A: Six-market model: } \\
\text { ingapore, South Korea, and the United States (VAR lag =4) }\end{array}$} \\
\hline & Trace test & L-max test & CV(Trace) & $\mathrm{CV}(\mathrm{L}-\max )$ \\
\hline $\mathrm{H}_{0}: \mathrm{r}=0$ & $94.97 *$ & $45.37 *$ & 94.15 & 39.37 \\
\hline $\mathrm{H}_{0}: \mathrm{r} \leq 1$ & 49.61 & 19.69 & 68.52 & 33.46 \\
\hline $\mathrm{H}_{0}: \mathrm{r} \leq 2$ & 29.92 & 14.71 & 47.21 & 27.07 \\
\hline $\mathrm{H}_{0}: \mathrm{r} \leq 3$ & 15.21 & 6.58 & 29.68 & 20.97 \\
\hline $\mathrm{H}_{0}: \mathrm{r} \leq 4$ & 8.63 & 5.18 & 15.41 & 14.07 \\
\hline $\mathrm{H}_{0}: \mathrm{r} \leq 5$ & 3.44 & 3.44 & 3.76 & 3.76 \\
\hline \multicolumn{5}{|c|}{ Panel B: Five-market models: } \\
\hline & Trace test & L-max test & CV(Trace) & $\mathrm{CV}(\mathrm{L}-\mathrm{max})$ \\
\hline $\mathrm{H}_{0}: \mathrm{r}=0$ & 51.84 & 21.37 & 68.52 & 33.46 \\
\hline $\mathrm{H}_{0}: \mathrm{r} \leq 1$ & 30.47 & 15.28 & 47.21 & 27.07 \\
\hline $\mathrm{H}_{0}: \mathrm{r} \leq 2$ & 15.18 & 7.15 & 29.68 & 20.97 \\
\hline $\mathrm{H}_{0}: \mathrm{r} \leq 3$ & 8.03 & 5.41 & 15.41 & 14.07 \\
\hline $\mathrm{H}_{0}: \mathrm{r} \leq 4$ & 2.62 & 2.62 & 3.76 & 3.76 \\
\hline
\end{tabular}

${ }^{3}$ In order to further verify our results, we also employ the Gregory and Hansen's (1996, Residual-based tests for cointegration in models with regime shifts, Journal of Econometrics, 70, 99-126) method to test the cointegrating relationship among the markets and the results are similar to those found in our earlier study indicating that there exists a long-term equilibrium relationship among markets with both South Korea and Singapore in the portfolios. 


\begin{tabular}{ccccc}
\hline \multicolumn{5}{c}{ Taiwan, Japan, Hong Kong, US, and singapore (VAR lag =6) } \\
\hline & Trace test & L-max test & CV(Trace) & CV(L-max) \\
\hline $\mathrm{H}_{0}: \mathrm{r}=0$ & 61.52 & 22.13 & 68.52 & 33.46 \\
$\mathrm{H}_{0}: \mathrm{r} \leq 1$ & 25.33 & 15.18 & 47.21 & 27.07 \\
$\mathrm{H}_{0}: \mathrm{r} \leq 2$ & 14.49 & 7.02 & 29.68 & 20.97 \\
$\mathrm{H}_{0}: \mathrm{r} \leq 3$ & 7.00 & 6.45 & 15.41 & 14.07 \\
$\mathrm{H}_{0}: \mathrm{r} \leq 4$ & 1.77 & 3.07 & 3.76 & 3.76 \\
\hline
\end{tabular}

\begin{tabular}{ccccc}
$\mathrm{H}_{0}: \mathrm{r} \leq 4$ & 2.05 & 2.05 & 3.76 & 3.76 \\
\hline \multicolumn{5}{c}{ Panel C: Four-market models: } \\
& \multicolumn{5}{c}{ Taiwan, Japan, Hong Kong, and Singapore (VAR lag = 6) } \\
\hline $\mathrm{H}_{0}: \mathrm{r}=0$ & \multicolumn{1}{c}{ Trace test } & L-max test & CV(Trace) & CV(L-max) \\
$\mathrm{H}_{0}: \mathrm{r} \leq 1$ & 38.17 & 16.61 & 47.21 & 27.07 \\
$\mathrm{H}_{0}: \mathrm{r} \leq 2$ & 21.56 & 11.17 & 29.68 & 20.97 \\
$\mathrm{H}_{0}: \mathrm{r} \leq 3$ & 10.39 & 7.05 & 15.41 & 14.07 \\
\hline \multicolumn{5}{c}{ Taiwan, Japan, Hong Kong, and South Korea (VAR lag =6) } \\
\hline $\mathrm{H}_{0}: \mathrm{r}=0$ & Trace test & L-max test & CV(Trace) & CV(L-max) \\
$\mathrm{H}_{0}: \mathrm{r} \leq 1$ & 32.37 & 17.48 & 47.21 & 27.07 \\
$\mathrm{H}_{0}: \mathrm{r} \leq 2$ & 14.88 & 6.15 & 29.68 & 20.97 \\
$\mathrm{H}_{0}: \mathrm{r} \leq 3$ & 8.74 & 5.36 & 15.41 & 14.07 \\
\hline
\end{tabular}


Long-Run Gains From International Equity Diversification:Taiwan's Evidence, 1995-2001 539

\begin{tabular}{|c|c|c|c|c|}
\hline \multicolumn{5}{|c|}{ Taiwan, Japan, Hong Kong, and US (VAR lag = 6) } \\
\hline & Trace test & L-max test & CV(Trace) & CV(L-max) \\
\hline $\mathrm{H}_{0}: \mathrm{r}=0$ & 40.32 & 19.84 & 47.21 & 27.07 \\
\hline $\mathrm{H}_{0}: \mathrm{r} \leq 1$ & 20.48 & 13.49 & 29.68 & 20.97 \\
\hline $\mathrm{H}_{0}: \mathrm{r} \leq 2$ & 7.00 & 5.24 & 15.41 & 14.07 \\
\hline $\mathrm{H}_{0}: \mathrm{r} \leq 3$ & 1.76 & 1.76 & 3.76 & 3.76 \\
\hline \multicolumn{5}{|c|}{ Taiwan, Japan, US and South Korea (VAR lag = 6) } \\
\hline & Trace test & L-max test & CV(Trace) & CV(L-max) \\
\hline $\mathrm{H}_{0}: \mathrm{r}=0$ & 31.72 & 15.18 & 47.21 & 27.07 \\
\hline $\mathrm{H}_{0}: \mathrm{r} \leq 1$ & 16.55 & 7.02 & 29.68 & 20.97 \\
\hline $\mathrm{H}_{0}: \mathrm{r} \leq 2$ & 9.53 & 6.45 & 15.41 & 14.07 \\
\hline $\mathrm{H}_{0}: \mathrm{r} \leq 3$ & 3.08 & 3.07 & 3.76 & 3.76 \\
\hline \multicolumn{5}{|c|}{ Taiwan, Japan, US and Singapore (VAR lag =6) } \\
\hline & Trace test & L-max test & CV(Trace) & CV(L-max) \\
\hline $\mathrm{H}_{0}: \mathrm{r}=0$ & 32.99 & 13.73 & 47.21 & 27.07 \\
\hline $\mathrm{H}_{0}: \mathrm{r} \leq 1$ & 19.27 & 11.62 & 29.68 & 20.97 \\
\hline $\mathrm{H}_{0}: \mathrm{r} \leq 2$ & 7.65 & 5.31 & 15.41 & 14.07 \\
\hline $\mathrm{H}_{0}: \mathrm{r} \leq 3$ & 2.34 & 2.34 & 3.76 & 3.76 \\
\hline \multicolumn{5}{|c|}{ Taiwan, Japan, Singapore and South Korea (VAR lag =6) } \\
\hline & Trace test & L-max test & CV(Trace) & CV(L-max) \\
\hline $\mathrm{H}_{0}: \mathrm{r}=0$ & $49.71 *$ & $34.40^{*}$ & 47.21 & 27.07 \\
\hline $\mathrm{H}_{0}: \mathrm{r} \leq 1$ & 15.31 & 7.15 & 29.68 & 20.97 \\
\hline $\mathrm{H}_{0}: \mathrm{r} \leq 2$ & 8.16 & 4.47 & 15.41 & 14.07 \\
\hline $\mathrm{H}_{0}: \mathrm{r} \leq 3$ & 3.67 & 3.67 & 3.76 & 3.76 \\
\hline \multicolumn{5}{|c|}{ Taiwan, Hong Kong, US, and South Korea (VAR lag = 6) } \\
\hline & Trace test & L-max test & CV(Trace) & CV(L-max) \\
\hline $\mathrm{H}_{0}: \mathrm{r}=0$ & 33.19 & 20.14 & 47.21 & 27.07 \\
\hline $\mathrm{H}_{0}: \mathrm{r} \leq 1$ & 13.06 & 5.95 & 29.68 & 20.97 \\
\hline $\mathrm{H}_{0}: \mathrm{r} \leq 2$ & 7.11 & 4.61 & 15.41 & 14.07 \\
\hline $\mathrm{H}_{0}: \mathrm{r} \leq 3$ & 1.77 & 3.07 & 3.76 & 3.76 \\
\hline \multicolumn{5}{|c|}{ Taiwan, Hong Kong, US, and Singapore (VAR lag = 6) } \\
\hline & Trace test & L-max test & CV(Trace) & CV(L-max) \\
\hline $\mathrm{H}_{0}: \mathrm{r}=0$ & 42.28 & 20.14 & 47.21 & 27.07 \\
\hline $\mathrm{H}_{0}: \mathrm{r} \leq 1$ & 22.66 & 12.21 & 29.68 & 20.97 \\
\hline $\mathrm{H}_{0}: \mathrm{r} \leq 2$ & 10.46 & 7.71 & 15.41 & 14.07 \\
\hline $\mathrm{H}_{0}: \mathrm{r} \leq 3$ & 2.75 & 2.75 & 3.76 & 3.76 \\
\hline \multicolumn{5}{|c|}{ Taiwan, Hong Kong, Singapore and South Korea (VAR lag = 6) } \\
\hline & Trace test & L-max test & CV(Trace) & CV(L-max) \\
\hline $\mathrm{H}_{0}: \mathrm{r}=0$ & $64.74^{*}$ & $43.90^{*}$ & 47.21 & 27.07 \\
\hline $\mathrm{H}_{0}: \mathrm{r} \leq 1$ & 20.85 & 14.26 & 29.68 & 20.97 \\
\hline $\mathrm{H}_{0}: \mathrm{r} \leq 2$ & 6.59 & 4.76 & 15.41 & 14.07 \\
\hline $\mathrm{H}_{0}: \mathrm{r} \leq 3$ & 1.82 & 1.82 & 3.76 & 3.76 \\
\hline
\end{tabular}




\begin{tabular}{ccccc}
\hline \multicolumn{5}{c}{ Taiwan, US, Singapore and South Korea (VAR lag = 6) } \\
\hline & Trace test & L-max test & CV(Trace) & CV(L-max) \\
\hline $\mathrm{H}_{0}: \mathrm{r}=0$ & $53.29^{*}$ & $38.97^{*}$ & 47.21 & 27.07 \\
$\mathrm{H}_{0}: \mathrm{r} \leq 1$ & 14.32 & 5.73 & 29.68 & 20.97 \\
$\mathrm{H}_{0}: \mathrm{r} \leq 2$ & 8.59 & 4.62 & 15.41 & 14.07 \\
$\mathrm{H}_{0}: \mathrm{r} \leq 3$ & 3.17 & 3.17 & 3.76 & 3.76 \\
\hline
\end{tabular}

Panel D: Three-market models:

Taiwan, Japan, and Hong Kong (VAR lag = 8)

\begin{tabular}{|c|c|c|c|c|}
\hline & Trace test & L-max test & CV(Trace) & CV(L-max) \\
\hline $\mathrm{H}_{0}: \mathrm{r}=0$ & 22.14 & 14.48 & 29.68 & 20.97 \\
\hline $\mathrm{H}_{0}: \mathrm{r} \leq 1$ & 7.65 & 5.34 & 15.41 & 14.07 \\
\hline $\mathrm{H}_{0}: \mathrm{r} \leq 2$ & 2.31 & 2.31 & 3.76 & 3.76 \\
\hline \multicolumn{5}{|c|}{ Taiwan, Japan, and Singaore $\quad($ VAR lag $=8)$} \\
\hline & Trace test & L-max test & CV(Trace) & CV(L-max) \\
\hline $\mathrm{H}_{0}: \mathrm{r}=0$ & 20.74 & 11.67 & 29.68 & 20.97 \\
\hline $\mathrm{H}_{0}: \mathrm{r} \leq 1$ & 9.07 & 5.40 & 15.41 & 14.07 \\
\hline $\mathrm{H}_{0}: \mathrm{r} \leq 2$ & 3.65 & 3.65 & 3.76 & 3.76 \\
\hline \multicolumn{5}{|c|}{ Taiwan, Japan, and South Korea (VAR lag = 9) } \\
\hline & Trace test & L-max test & CV(Trace) & CV(L-max) \\
\hline $\mathrm{H}_{0}: \mathrm{r}=0$ & 20.65 & 11.64 & 29.68 & 20.97 \\
\hline $\mathrm{H}_{0}: \mathrm{r} \leq 1$ & 9.00 & 9.39 & 15.41 & 14.07 \\
\hline $\mathrm{H}_{0}: \mathrm{r} \leq 2$ & 3.66 & 3.66 & 3.76 & 3.76 \\
\hline \multicolumn{5}{|c|}{ Taiwan, Japan, and US (VAR lag = 8) } \\
\hline & Trace test & L-max test & CV(Trace) & CV(L-max) \\
\hline $\mathrm{H}_{0}: \mathrm{r}=0$ & 22.28 & 13.09 & 29.68 & 20.97 \\
\hline $\mathrm{H}_{0}: \mathrm{r} \leq 1$ & 9.19 & 6.29 & 15.41 & 14.07 \\
\hline $\mathrm{H}_{0}: \mathrm{r} \leq 2$ & 2.90 & 2.90 & 3.76 & 3.76 \\
\hline \multicolumn{5}{|c|}{ Taiwan, Hong Kong, and Singapore (VAR lag = 8) } \\
\hline & Trace test & L-max test & CV(Trace) & CV(L-max) \\
\hline $\mathrm{H}_{0}: \mathrm{r}=0$ & 23.75 & 12.59 & 29.68 & 20.97 \\
\hline $\mathrm{H}_{0}: \mathrm{r} \leq 1$ & 11.15 & 9.41 & 15.41 & 14.07 \\
\hline $\mathrm{H}_{0}: \mathrm{r} \leq 2$ & 1.74 & 1.74 & 3.76 & 3.76 \\
\hline \multicolumn{5}{|c|}{ Taiwan, Hong Kong, South Korea (VAR lag = 8) } \\
\hline & Trace test & L-max test & CV(Trace) & CV(L-max) \\
\hline $\mathrm{H}_{0}: \mathrm{r}=0$ & 15.89 & 7.83 & 29.68 & 20.97 \\
\hline $\mathrm{H}_{0}: \mathrm{r} \leq 1$ & 8.07 & 5.09 & 15.41 & 14.07 \\
\hline $\mathrm{H}_{0}: \mathrm{r} \leq 2$ & 2.98 & 2.98 & 3.76 & 3.76 \\
\hline \multicolumn{5}{|c|}{ Taiwan, Hong Kong, and US (VAR lag = 8) } \\
\hline & Trace test & L-max test & CV(Trace) & CV(L-max) \\
\hline $\mathrm{H}_{0}: \mathrm{r}=0$ & 25.28 & 16.95 & 29.68 & 20.97 \\
\hline $\mathrm{H}_{0}: \mathrm{r} \leq 1$ & 8.33 & 5.14 & 15.41 & 14.07 \\
\hline $\mathrm{H}_{0}: \mathrm{r} \leq 2$ & 3.19 & 3.19 & 3.76 & 3.76 \\
\hline
\end{tabular}


Long-Run Gains From International Equity Diversification:Taiwan's Evidence, 1995-2001 541

\begin{tabular}{|c|c|c|c|c|}
\hline \multicolumn{5}{|c|}{ Taiwan, US and, Singapore (VAR lag = 8) } \\
\hline & Trace test & L-max test & CV(Trace) & CV(L-max) \\
\hline $\mathrm{H}_{0}: \mathrm{r}=0$ & 19.47 & 10.28 & 29.68 & 20.97 \\
\hline $\mathrm{H}_{0}: \mathrm{r} \leq 1$ & 9.19 & 5.57 & 15.41 & 14.07 \\
\hline $\mathrm{H}_{0}: \mathrm{r} \leq 2$ & 3.62 & 3.62 & 3.76 & 3.76 \\
\hline \multicolumn{5}{|c|}{ Taiwan, US and, South Korea (VAR lag = 8) } \\
\hline & Trace test & L-max test & CV(Trace) & CV(L-max) \\
\hline $\mathrm{H}_{0}: \mathrm{r}=0$ & 14.63 & 6.18 & 29.68 & 20.97 \\
\hline $\mathrm{H}_{0}: \mathrm{r} \leq 1$ & 8.54 & 5.62 & 15.41 & 14.07 \\
\hline $\mathrm{H}_{0}: \mathrm{r} \leq 2$ & 2.83 & 2.83 & 3.76 & 3.76 \\
\hline \multicolumn{5}{|c|}{ Taiwan, Singapore, and South Korea (VAR lag = 8) } \\
\hline & Trace test & L-max test & CV(Trace) & CV(L-max) \\
\hline $\mathrm{H}_{0}: \mathrm{r}=0$ & $34.69^{*}$ & $26.78^{*}$ & 29.68 & 20.97 \\
\hline $\mathrm{H}_{0}: \mathrm{r} \leq 1$ & 7.92 & 4.98 & 15.41 & 14.07 \\
\hline $\mathrm{H}_{0}: \mathrm{r} \leq 2$ & 2.93 & 2.93 & 3.76 & 3.76 \\
\hline \multicolumn{5}{|c|}{ Panel E: Two-market models: Taiwan and Japan (VAR lag = 4) } \\
\hline & Trace test & L-max test & CV(Trace) & CV(L-max) \\
\hline $\mathrm{H}_{0}: \mathrm{r}=0$ & 9.95 & 6.33 & 15.41 & 14.07 \\
\hline $\mathrm{H}_{0}: \mathrm{r} \leq 1$ & 3.62 & 3.62 & 3.76 & 3.76 \\
\hline \multicolumn{5}{|c|}{ Taiwan and Hong Kong (VAR lag = 4) } \\
\hline & Trace test & L-max test & CV(Trace) & CV(L-max) \\
\hline $\mathrm{H}_{0}: \mathrm{r}=0$ & 11.87 & 8.97 & 15.41 & 14.07 \\
\hline $\mathrm{H}_{0}: \mathrm{r} \leq 1$ & 2.90 & 2.90 & 3.76 & 3.76 \\
\hline \multicolumn{5}{|c|}{ Taiwan and Singapore (VAR lag = 4) } \\
\hline & Trace test & L-max test & CV(Trace) & $\mathrm{CV}(\mathrm{L}-\mathrm{max})$ \\
\hline $\mathrm{H}_{0}: \mathrm{r}=0$ & 10.79 & 7.39 & 15.41 & 14.07 \\
\hline $\mathrm{H}_{0}: \mathrm{r} \leq 1$ & 3.40 & 3.40 & 3.76 & 3.76 \\
\hline \multicolumn{5}{|c|}{ Taiwan and South Korea (VAR lag = 4) } \\
\hline & Trace test & L-max test & CV(Trace) & CV(L-max) \\
\hline $\mathrm{H}_{0}: \mathrm{r}=0$ & 7.53 & 4.60 & 15.41 & 14.07 \\
\hline $\mathrm{H}_{0}: \mathrm{r} \leq 1$ & 2.92 & 2.92 & 3.76 & 3.76 \\
\hline \multicolumn{5}{|c|}{ Taiwan and US (VAR lag $=21)$} \\
\hline & Trace test & L-max test & CV(Trace) & CV(L-max) \\
\hline $\mathrm{H}_{0}: \mathrm{r}=0$ & 8.39 & 5.14 & 15.41 & 14.07 \\
\hline $\mathrm{H}_{0}: \mathrm{r} \leq 1$ & 3.25 & 3.25 & 3.76 & 3.76 \\
\hline \multicolumn{5}{|c|}{ Panel F: Singapore and South Korea (VAR lag = 4) } \\
\hline & Trace test & L-max test & CV(Trace) & CV(L-max) \\
\hline $\mathrm{H}_{0}: \mathrm{r}=0$ & $27.02 *$ & $23.42 *$ & 15.41 & 14.07 \\
\hline $\mathrm{H}_{0}: \mathrm{r} \leq 1$ & 3.60 & 1.67 & 3.76 & 3.76 \\
\hline
\end{tabular}

Note: $1 . \mathrm{CV}$ is the abbreviation for the critical value.

2. Critical values are taken from Osterwald-Lenum (1992).

3. * indicates significance at the $5 \%$ level.

4. Schwartz Bayesian information criteria (SBC), is used to select the number of lags required in the cointegrating test. The computed Ljung-Box Q-statistics also indicate that the residuals are white noise. The Lagrange multiplier test also indicates no evidence of ARCH effects in systems. 


\section{Conclusion}

This study provides evidence that there exist no potential long-run portfolio diversification gains to Taiwan investors from diversifying in the stock markets of its major trading partners, namely those of Hong Kong, Japan, Singapore, South Korea, and the United States, in the sense that there is evidence of cointegrating relationship among these stock markets. However, our results show that the dropping of both Singapore and South Korea markets from the market portfolio may lead to a rejection of cointegration and hence imply gains from diversification. Our results argue that the analysis of more extensive portfolios and the drawing of conclusions regarding portfolio diversification must be carried out with great care for Taiwan investors. These findings can be valuable to Taiwan individual investors and financial institutions evaluating international portfolios, as well as institutions such as superannuation funds holding internationally diversified long-run investment portfolios.

Received January 2002, Accepted 27 January 2003

\section{References}

Arshanapalli, B., and Doukas. J. (1993), "International stock market linkages: Evidence from the pre- and post-October 1987 period," Journal of Banking and Finance, 93-208.

Arshanapalli, B., Doukas, J., and Lang, Larry H. P. (1995), "Pre and post-October 1987 stock market linkages between U.S. and Asian markets," Pacific-Basin Finance Journal, 3, 57-73.

Bierens, H. J. (1997), "Nonparametric cointegration analysis," Journal of Econometrics, 77, 379-404.

Campbell, J. and Perron, Peter. (1991), "What macroeconomists should know about unit roots, edited by O. Blanchard and S. Fisher," NBER macroeconomics annual, MIT Press, Cambridge, MA.

Chan, K.C., Gup, B. E., and Pan, M. S. (1992), "An empirical analysis of stock prices in major Asian markets and the United States," The Financial Review, 27, 289-308.

Chowdhury, Abdur R. (1994), "Stock market interdependencies: evidence from the Asian NIEs," Journal of Macroeconomics, 16, 4, 629-651.

Dickey, David. A. and Fuller, W. A. (1981), "Likelihood ratio statistics for autoregressive time series with a unit root," Econometrica, 49, 4, 1057-1072.

Engle, Robert F. and Granger, C. W. J. (1987), "Co-integration and error correction: representation, estimation and testing," Econometrica, 55, 251-276.

Gonzalo, Jesus (1994), "Five alternative methods of estimating long-run equilibrium 
Long-Run Gains From International Equity Diversification:Taiwan's Evidence, 1995-2001 543

relationships," Journal of Econometrics, 203-233.

Gregory, A.W. and Hansen, B E. (1996) Residual-based tests for cointegration in models with regime shifts, Journal of Econometrics, 70, 99-126.

Granger, C. W. J. (1981), "Some Properties of Time Series Data and Their Use in Econometric Model Specification," Journal of Economics, 16, 121-130.

Hassan, M. Kabir. and Naka, Atsuyuki. (1996), "Short-run and long-run dynamic linkages among international stock markets," International Review of Economics and Finance, 5, 4, 387-405.

Johansen, S. (1988), "Statistical analysis of cointegration vectors," Journal of Economics Dynamic and Control, 12, 231-254.

Johansen, S. and Juselius, K. (1990), "Maximum likelihood estimation and inference on cointegration - with application to the demand for money," Oxford Bulletin of Economics and Statistics, 2, 169-210.

Kanas, Angelos. (1998), "Linkages between the US and European equity markets: further evidence from cointegration tests," Applied Financial Economics, 8, 607-614.

Kremers, J.M., Erisccos, N.R., and Dolado, J. J. (1992), "The power of cointegration tests, Oxford Bulletin of Economics and Statistics 54, 325-346.

Kwan, Andy C. C., Sim, Ah-Boon and Cotsomitis, John A. (1995), "The Causal relationships between equity indices on world exchanges," Applied Economics, 27, 33-37.

Lee, Bong-Soo and Jeon, Bang Nam. (1995), "Common stochastic trends and predictability of international stock prices," Journal of the Japanese and International Economics, 9, 245-277.

Mackinnon, James. (1991), Critical values for cointegration tests in long-run economic relationships - Readings in Cointegration, edited by Engle and Granger, Oxford University Press.

Masih, A. M. M. and Masih, R. (1997a), “A comparative analysis of the propagation of stock market fluctuations in alternative models of dynamic causal linkages," Applied Financial Economics, 7(1), pp.59-74

, (1997b), "Dynamic Linkages and the Propagation Mechanism Driving Major International Stock Markets: An Analysis of the Pre- and Post-Crash Eras," The Quarterly Review of Economics and Finance, 37(4), 859-885

McDonald, R. and Taylor, M. (1989), "Foreign exchange market efficiency and cointegration: some evidence from the recent float," Economic Letters, 29, 63-68.

Nelson, Charles R and Plosser, Charles I. (1982), "Trends and random walks in macroeconomic time series," Journal of Monetary Economics, 10, 139-162.

Newey, W. K., and West, K. D. (1987), "A simple, positive semi-definite heteroskedasticity and autocorrelation consistent covariance matrix," Econometrica, 3, 703-708.

Osterwald-Lenum, M. (1992), "A note with fractiles of the asymptotic distribution of the likelihood cointegration rank test statistics," Oxford Bulletin of Economics and Statistics, 54, 889-895. 
Phillips, P. C. and Perron, P. (1988), "Testing for a unit root in time series regression," Biometrika, 75, 335-346.

Phillips, P. C. and Ouliaris, S. (1990), "Asymptotic propertities of residuals based tests for cointegration," Econometrics, 58, 165-193.

Roger, John H. (1994), "Entry barriers and price movements between major and emerging stock markets," Journal of Macroeconomics, 16, 2, 221-241. 